REVISTA INTERNACIONAL DE CIENCIAS DEL DEPORTE International Journal of Sport Science

Rev. int. cienc. deporte

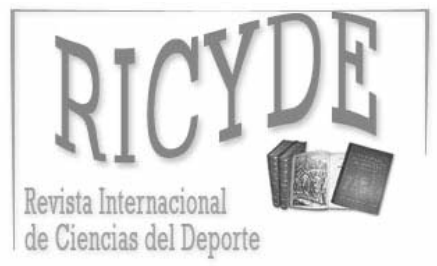

International Journal of Sport Science VOLUMEN VI - AÑO VI

Páginas:37-56 ISSN:1885-3137

No 18 - Enero - 2010

\title{
What are we being told about how to teach games? A three-dimensional analysis of comparative research into different instructional studies in Physical Education and School Sports.
}

\section{¿Qué sabemos acerca de la enseñanza de los juegos deportivos? Un análisis tridimensional de la investigación comparativa de diferentes estudios de enseñanza en Educación Física Escolar.}

\author{
Antonio Méndez Giménez \\ Universidad de Oviedo, Asturias. España \\ Alfonso Valero Valenzuela \\ Universidad de Murcia. España \\ Ashley Casey \\ Universidad de Bedforshire. Reino Unido
}

\begin{abstract}
Determining what pedagogical approach could be most effective in delivering the desired learning outcomes in teaching games has been one of the more relevant concerns for physical education teachers, coaches and researches in the last few decades. Nevertheless, until recently, the research carried out in this field has been little profuse, has met with several difficulties and has been made from different perspectives, which has complicated its analysis altogether. The present study follows three main objectives: a) to analyse the nature of the interventions used in the comparative investigation directed to teaching sports, b) to determine the effects of the levels of treatment and, c) to outline some didactic consequences. Twenty comparative studies were selected for a systematic review. With regards to the instructional approaches the teaching of games three lines of analysis were contemplated: 1 ) Studies that compare interventions using the part- vs. whole-task teaching methods. 2) Studies that compare the teaching via direct vs. indirect instruction. 3 ) Studies that compare skills-based approach with alternative approaches, especially the direct instruction model versus the TGfU model. Based on the three paradigms, it was shown that the whole-task teaching method generates both greater satisfaction and security for children in their own performance. Indirect instructional techniques have a positive influence at an affective and social level, as well as on their decision making. The alternative approaches to the skills-based approach examined show that a greater degree of understanding of game play and more affective, and enjoyable behavior was obtained through tactics-based approach. The three-dimensional review reported in this paper could be used as complementary research to aid in future longitudinal studies such as the investigation that look at the integration of diverse instructional studies.
\end{abstract}

Key words: teaching methods; instructional techniques; instruction model; TGfU; physical education; sport.

\section{Resumen}

Determinar qué aproximación pedagógica puede ser más eficaz para conseguir los resultados de aprendizaje deseados en la enseñanza de los juegos deportivos ha sido una de las preocupaciones más relevantes de profesores de educación física, entrenadores e investigadores en las últimas décadas. Sin embargo, hasta hace poco la investigación realizada en este campo ha sido poco profusa, ha contado con varias dificultades y ha sido abordada desde diferentes perspectivas, lo que ha dificultado su análisis en conjunto. El presente estudio pretende conseguir tres objetivos: a) analizar la naturaleza de las intervenciones empleadas en la investigación comparativa dirigida a la enseñanza deportiva, b) determinar los efectos de cada uno de los niveles de tratamiento y, c) extraer posibles implicaciones didácticas. Se realizó una revisión sistemática de los 20 estudios comparativos seleccionados. Se contemplaron tres líneas de análisis de la enseñanza de juegos deportivos: 1) Estudios que comparan los métodos analíticos versus métodos globales. 2) Estudios que comparan la enseñanza mediante instrucción directa versus búsqueda (indirecta), y 3) Estudios que comparan modelos tradicionales con modelos alternativos, en especial, el modelo técnico versus el modelo comprensivo (TGfU). Basándonos en los tres paradigmas señalados, se encontró que el método de enseñanza global genera mayor satisfacción y seguridad para los niños en su propio rendimiento. Las técnicas de enseñanza indirectas tienen una influencia positiva a nivel afectivo y social, así como en su toma de decisión. La aproximación alternativa a la enseñanza técnica mostró que se obtenía un mayor grado de comprensión del juego y un comportamiento más afectivo y mayor diversión mediante la aproximación basada en la táctica. Creemos que la revisión tridimensional divulgada en este artículo podría utilizarse como investigación complementaria para ayudar en estudios longitudinales futuros, por ejemplo, en la investigación que analiza la integración de diversos enfoques de enseñanza.

Palabras clave: métodos de enseñanza; técnicas de enseñanza; modelo de enseñanza; TGfU ; educación física; deporte.

Correspondencia/correspondence: Antonio Méndez Giménez

C/ Aniceto Sela, s/n. Despacho 239. Facultad de Ciencias de la Educación. 33005 Oviedo, (España)

e-mail: mendezantonio@uniovi.es 
Méndez, A.; Valero, A.; Casey, A. (2010). What are we being told about how to teach games? A threedimensional analysis of comparative research into different instructional studies in Physical Education and School Sports. Revista Internacional de Ciencias del Deporte. 18(6), 37-56.

http://www.cafyd.com/REVISTA/01803.pdf

Since, as Holt, Strean, and García (2002, p.162) indicate, "games have been a major part of $\checkmark$ most physical education programs, often constitiuting a majority of time in physical education curricula" it is important that teachers and teacher educators have a good understanding of what makes for good practice in games teaching (see Hardman and Marshall, 2005; Metzler, 2005; Oslin and Mitchell, 1998). Curtner-Smith, Todorovich, McCaughtry and Lacon (2001, p. 178) hypothesized that, in order to meet the requirements of new pedagogical demands of the national curriculum in the UK (which are similar to those of the United Stated) teachers would "need to shift from the exclusive use of direct, teachercentred, or reproductive styles of teaching to employing more indirect, pupil-centred, or productive styles”. It is no longer appropriate to teach to the industry standards of teachercentredness (Casey, 2006) and instead teachers need to answer the question recently asked by Tannehill and Lund (2005, p. 30) 'how do we design instruction to facilitate learning?'.

Determining what pedagogical approach will be most effective in delivering the desired learning outcomes (technique, tactics, enjoyment, knowledge/understanding, social-affective and motivational) depends on both the context and the characteristics of the learners. Despite the diversity of both these facets of education such a choice has become a key question for educators and researchers in the field of PE. In fact, research aimed at comparing skills-based and tactics-based approaches of sports instruction has given rise to substantial interest in recent decades in such diverse geographical areas as the USA, Canada, the UK, France, Finland, Australia, Greece and Spain (see Allison \& Thorpe, 1997; Blomqvist, Luhtanen \& Laakso, 2001; Boutmans, 1983; French, Werner, Rink, Taylor \& Hussey 1996; French, Werner, Taylor, Hussey \& Jones, 1996; Gabriele \& Maxwell, 1995; Griffin, Oslin \& Mitchell, 1995; Lawton, 1989; McPherson \& French, 1991; Méndez, 1999; Metzler, 1986; Turner \& Martinek, 1992, 1999).

However, Rink, French and Tjeerdsma (1996) underlined the difficulty of carrying out valid comparisons of studies that analysed the effects of a skills-based and a tactics-based approach to the teaching of sports. They cited, among other reasons, the fact that the designs of the research studies employed have been individually distinct as the major limitation. Added to this difficulty, they also report other limitations, such as the variation in the games chosen, the age of the participants, the length and nature of the intervention, the diverse research variables chosen and their form of measurement. To this list, Kirk (2005) and Kirk and McPhail (2002) proposed that the equivocal nature of the findings may also be due to their treatment of Teaching Games for Understanding (TGfU) and technique-based approaches as alternative forms of practice.

Gréhaigne, Godbout and Bouthier (1999) acknowledged the existence of at least four facets that should form the basis of any discussion on the teaching and learning of team sports that might act as a focus for this debate: (a) the contribution concerning the approaches to and instruction technique employed in sports games; (b) the use of direct or indirect strategies in the light of the constructivist versus strictly cognitivist perspectives of the teaching-learning process; (c) pedagogical content knowledge; and finally, (d) the importance of clarifying a number of concepts associated with tactics and strategic aspects of games and sports.

A decade since the first review by Rink et al. (1996) of the six most relevant studies that compared the tactics-based approach with the skills-based approach (which led them to ambiguous conclusions derived from the difficulties to compare so different studies), we believe that the debate may justifiably be reopened in light of the extensive research carried out since then. In the same way, we agree with Butler, Griffin, Lombardi, Nastasi and Robson 
Méndez, A.; Valero, A.; Casey, A. (2010). What are we being told about how to teach games? A threedimensional analysis of comparative research into different instructional studies in Physical Education and School Sports. Revista Internacional de Ciencias del Deporte. 18(6), 37-56.

http://www.cafyd.com/REVISTA/01803.pdf

(2003) that this debate can help us examine and clarify our values, and promoting healthy change, that is vital to our own growth as educators. In this paper, we make a number of considerations when analysing and setting out the research on sports approaches with the aim of determining the limits of the debate. Specifically, we suggest a closer examination of the different problematic dimensions that relate to the nature of the intervention that have been used in the research design (two of which coincide with the first two facets of the debate mentioned by Gréhaigne et al., 1999).

\section{Method}

The authors conducted a systematic review of the investigations that have compared different methodological interventions in school teaching sports, focusing the search towards the studies carried out from 1980 to 2005. To be including in the review, the papers had to fulfil the following criteria: a) to be investigations published in scientific journals specialized or in proceedings of national and international congresses, b) to have compared results between groups with experimental or cuasi-experimental designs, and c) to have been published in Spanish, Portuguese, English or French.

The search was carried out in the following data bases (EBSCO, MEDLINE, SPORTDiscus, Psychinfo, TESEO, as well as in proceedings of congresses). In addition, the references of the found studies were assessed and it was consulted with specialists in physical activity to identify other relevant researches. Once the difficulties to use appropriate and specific terms in English were overcome, the following descriptors were introduced in the search: method, teaching games/sports, comparative analysis, instructional technique, direct instruction, Teaching Games for Understanding, teaching models, instructional approach, technique approach/model, traditional model, tactical model, part-task teaching method, and whole-task teaching method.

Several documents were excluded for different reasons: lack of rigour, duplicity of a same investigation, irrelevant data, or isolated cases of comparison. For the revision of the analysis categories we selected those most frequently used in the studies. Finally, the variables were in depth analysed, displaying the data and results of greater relevance by means of a synthesistable.

\section{The Dimensions of the Debate: Towards a Conceptual Clarification}

This paper is based upon an in-depth review of the most relevant research, to 2005, into the comparison of sports instructional approaches. This review revealed three major lines of analysis: 1) Studies that compare interventions using the part- vs. whole-task teaching methods, 2) studies that compare instructional techniques or ways of providing information, i.e. the teaching of technical and tactics aspects via direct instruction or indirect learning, and 3) studies that compare instructional approaches to sports initiation, that is, skills-based approach with alternative approaches, especially the direct instruction model versus the TGfU model (see Tables I-III).

Part-task vs. whole-task teaching methods

The first aspect revealed by the analysis was the type of activities that are presented to the learner, which range from analytical exercises, through simplified or modified games to the most comprehensive proposals akin to the full and internationally recognised game. 
Méndez, A.; Valero, A.; Casey, A. (2010). What are we being told about how to teach games? A threedimensional analysis of comparative research into different instructional studies in Physical Education and School Sports. Revista Internacional de Ciencias del Deporte. 18(6), 37-56.

http://www.cafyd.com/REVISTA/01803.pdf

Part-task vs. whole-task teaching methods are two particular ways of addressing the different tasks that make up the progression of instruction of a particular motor skill nevertheless a continuum between both of them could be understood. The more analytical the task is, the more it approaches technical learning. On the other hand, the more the teacher seeks to give his or her students an understanding of the game then the more the proposal is orientated towards the complete sport. The debate focuses on what type of strategies to emphasize: part or whole strategies - in which part is analytical and whole encompasses the entire game although it is understood that both options are necessary in the sports instruction-learning process.

\section{Instructional Techniques}

The second aspect is the Instructional Technique (IT) employed, i.e. the way of transmitting the technical and tactical concepts of the game. The IT is defined as the way in which the instructor transmits the information and the skills to his or her pupils (Gréhaigne et al., 1999, Kirk, 2005; Metzler, 2005; Mosston \& Ashworth, 1986). We differentiate between the following instructional techniques:

Direct instruction. By means of direct instruction, a model of correct execution is provided. The teacher decides practically everything as regards lesson organization, choice of programme, time allocation, and the degree of participation of each pupil in each activity. The same task is taught to all the children at the same time, and often repeated again and again over a number of years.

Indirect instruction or pupil-centred method. The indirect method is distinguished by the main role of the pupils who do not simply receive and carry out the teacher's decisions but share in decision taking with respect to the preparation and running of the lesson and its assesment.

Combined instruction technique. The third type of IT involves the combined use of the two previous methods. The teacher uses one technique or another to present the information in each session or teaching unit on the basis of number factors he or she indentifies in the educational process, for example, motivation, pupil experience and comprehension, time of day, space and difficulty of the task.

\section{Instructional approaches in sports initiation}

The third aspect of this paper attempts to compare the dominant technical or skills-based approach of teaching which prioritises technique over tactics with alternative tactics-based approaches which prioritises the reverse. While current thinking focuses on when to introduce tactics or technical skills and how these should be combined rather than which approach is better (Holt et al., 2002; Hooper, 2002; McMorris, 1998) research has previously (and importantly from the teachers perspective) explored the relative strengths and weakness of different approaches to teaching sports.

The skills-based approach. This approach focuses first on the teaching of the skills of the game before going on to introduce tactical knowledge, once a skills base has been developed. The skills-based approach in its purest state suggests that the pupils repeat the most relevant techniques of the game and once they are capable of executing them, they move on to play modified forms and/or the adult game. This focuses on the content rather than the pupils.

The tactics-based approaches. These alternative approaches start by attempting to give the pupils a comprehension of the common principles of the games and of game play before refining pupil skills. The most pure approach sustains that the pupils do not move on to 
Méndez, A.; Valero, A.; Casey, A. (2010). What are we being told about how to teach games? A threedimensional analysis of comparative research into different instructional studies in Physical Education and School Sports. Revista Internacional de Ciencias del Deporte. 18(6), 37-56.

http://www.cafyd.com/REVISTA/01803.pdf

refining their skills without having understood the essence of the game. One of these alternative approaches originated at Loughborough University when lecturers Rod Thorpe and David Bunker (Bunker \& Thorpe, 1982) and subsequently Len Almond (Thorpe, Bunker, \& Almond, 1986) developed an approach known as Teaching Games for Understanding (TGfU). Since the conception of this pioneering British approach, similar approaches have been developed in the USA, such as the Tactical Games Model (Griffin, Mitchell \& Oslin, 1997), and in Australia, such as Game Sense (Australian Sports Commission, 1997).

The combined approaches. Combined approaches are driven by the belief that technique and tactics go hand in hand and should be tackled simultaneously in accordance with the development of the child. Furthermore pupils rarely develop technical and tactical knowledge at the same pace in the teaching-learning process. The results that follow suggest that some pupils cannot or do not want to understand by themselves the tactical requirements of the sport (in some cases due to a lack of receptivity of reflexive approaches). This may place a limit on the number of pedagogical approach that can be used with them and could ultimately curtail the number of 'real' experiences that they have of a given game.

The focus of this paper is on how pedagogues might proceed in order to make instruction more efficient, i.e. from technique to tactics or from tactics to technique and strives to focus on either the pupil or on the contents as we perceive these to be the key questions in this debate.

\section{Analysis of Comparative Studies into Game Instruction}

This article is an attempt to follow the research line initiated by Rink et al. (1996) that looked at the comparative studies in game instruction. Despite some critics to this sort of research (Holt et al., 2002; Rink, 2001) we consider that the three dimensional analysis at the centre of this revision could help to clarify what we are being academically told about how to teach games. After a systematic review of twenty studies published over recent decades that compared sports instructional studies in depth, we gathered together the most relevant data and results in three summary tables (see Tables I, II and III). These tables are modifications of the one proposed by Rink et al. (1996). To this original model we have added to, modified and adapted the content in an effort to summarise the twenty research studies that had been considered key works. We have then grouped them in each of the three lines of research or the predominant teaching intervention.

Part- vs. whole-task teaching method

Chronologically, comparative research into whole and analytical methods in sports instruction were the first to arouse interest in the academic community and focused on team and invasion sports (Boutmans, 1983; Durán \& Lasierra, 1987; McMorris, 1988). This dimension of the analysis, is not especially profuse (see Table I), and it is restricted to the school setting and in particular to the initial stage of secondary education.

The teaching units were short or medium in duration (one a week, and between 6 to 15 lessons) and the number of subjects per group was lower than usual in Physical Education classes (approximately 25 per group in the Spanish context).

It should also be noted that there are different methodology and treatment verification levels, which makes comparisons between studies difficult. For instance, the part-task teaching method (progressive analytical method) in the study by McMorris (1988) was initially based on the teaching of the key techniques of soccer without opposition, then moved gradually on to situations with opposition (eg. 3x1, 4x2) in which opposing and/or collaborating players 
Méndez, A.; Valero, A.; Casey, A. (2010). What are we being told about how to teach games? A threedimensional analysis of comparative research into different instructional studies in Physical Education and School Sports. Revista Internacional de Ciencias del Deporte. 18(6), 37-56.

http://www.cafyd.com/REVISTA/01803.pdf

are gradually added, concluding with small-sided game situations. The small-sided games strategy consisted in a 6x6 game, using a "freeze-replay" teaching game and the teacher "freeze" the game when he wished to make a coaching point. After that, the play re-started with the players carrying out the correct decision or skill.

Nevertheless, the part-task teaching method in the study by Durán and Lasierra (1987) began with an explanation and a series of exercises to aid the assimilation and application of basic hockey skills before moving into a second phase to rule-based application in small-sided games (with numerical equality or superiority in attack) and then to attack and defense systems during formal play.

With respect to the pupil-related dependent variables (see Table I), it seems that only 6 treatment sessions (even with a minimum weekly frequency) would be sufficient to induce slight improvements in the development of technical skills, irrespective of the teaching method employed (Durán \& Lasierrra, 1987).

However, significant differences were not found between the two teaching interventions (whole versus part teaching method) except in the work of Durán and Lasierra (1987), in which the group that used a whole-task teaching method carried out the closed slalom test significantly better than the analytical group. At the same time the whole practice group obtained better results in an open test developed over a circuit that required a greater level of adaptation than the analytical group.

As far as performance in play situations is concerned, the results were ambiguous. In the basketball study by Boutmans (1983), the analytical group obtained improvements in game skills, while in the study by the same author on volleyball, the whole group was found to obtain improvements in this skill. The study by McMorris (1988), which was shorter in duration (six sessions), did not find differences between the interventions.

Finally, the research by Boutmans (1983) and Durán and Lasierra (1987) indicates that the whole practice sessions generated a greater degree of performance satisfaction and security in the pupils, than receive analytical instruction in which pupils presented a greater sense of insecurity or frustration due to not achieving the expected mastery of the sport.

In addition to the aforementioned differences between the studies, the designs employed presented other weaknesses. In the three studies, and especially in the work of McMorris (1988), the total number of subjects was low. In general, the reduced duration of the interventions may have prevented more conclusive results being obtained. Moreover, neither the pupil knowledge acquisition variable nor aspects related to the repercussions for the teacher was included when carrying out teaching from one teaching approach or another. 
Méndez, A.: Valero, A.; Ashley, C. (2010). What are we being told about how to teach games? A three-dimensional analysis of comparative research into different instructional studies in Physical Education and School Sports. Revista Internacional de Ciencias del Deporte. 18(6), 37-56. http://www.cafyd.com/REVISTA/01803.pdf

Table I. Comparison of Research Studies as a Function of the Part- vs. whole-task teaching method.

\begin{tabular}{|c|c|c|c|}
\hline \multirow[b]{2}{*}{$\begin{array}{l}\text { Whole vs. part } \\
\text { Strategy }\end{array}$} & \\
\hline & Boutmans (1983) & Durán and Lasierra (1987) & McMorris (1988) \\
\hline $\begin{array}{l}\text { Nature of the } \\
\text { research }\end{array}$ & Comparison of a whole method versus a part method & $\begin{array}{c}\text { Comparison of a whole method versus a part instruction } \\
\text { method }\end{array}$ & $\begin{array}{l}\text { Comparison of a progressive } \\
\text { analytical method versus the small- } \\
\text { sided games method }\end{array}$ \\
\hline Sport & Basketball & Indoor hockey & Soccer \\
\hline Context & Physical Education & Physical Education & Physical Education \\
\hline Age & 13 year olds & $15-16$ year olds & 11-12 year olds \\
\hline Gender & Females & Males and females & Males and females \\
\hline $\begin{array}{l}\text { No. of sessions } \\
\text { Frequency }\end{array}$ & $\begin{array}{c}10 \\
1 \text { per week }\end{array}$ & $\begin{array}{c}\text { Whole instruction: } 15 \\
\text { Analytical instruction: } 16\end{array}$ & $\begin{array}{c}6 \\
1 \text { per week }\end{array}$ \\
\hline $\begin{array}{l}\text { Duration of the } \\
\text { session }\end{array}$ & 60 minutes & 45 minutes & $\begin{array}{l}\text { Not specified, though } 60 \text { minutes is } \\
\text { understood }\end{array}$ \\
\hline $\begin{array}{l}\text { No. of groups and } \\
\text { subjects per group }\end{array}$ & $\begin{array}{l}1 \text { group: } 11 \text { subjects } \\
1 \text { group: } 20 \text { subjects }\end{array}$ & $\begin{array}{c}2 \text { groups of } 20 \text { subjects ( } 15 \text { males and } 5 \text { females in each } \\
\text { group) }\end{array}$ & 2 groups of 12 subjects \\
\hline Total no. of sessions & $\begin{array}{ll}31 & 30\end{array}$ & 40 & 24 \\
\hline Technical skills & $\begin{array}{l}\text { Both groups improved significantly. } \\
\text { There were no significant differences between groups }\end{array}$ & $\begin{array}{l}\text { The analytical group was better in the slalom test. The } \\
\text { Whole practice group was better in the circuit }\end{array}$ & $\begin{array}{l}\text { Both groups improved in passing } \\
\text { and support techniques. There were } \\
\text { no differences between groups }\end{array}$ \\
\hline $\begin{array}{l}\text { Knowledge } \\
\text { acquisition }\end{array}$ & This variable was not contemplated in the research & This variable was not contemplated in the research & $\begin{array}{l}\text { This variable was not contemplated } \\
\text { in the research }\end{array}$ \\
\hline \multirow[t]{2}{*}{$\begin{array}{l}\text { Performance in the } \\
\text { practice of the game }\end{array}$} & $\begin{array}{cc}\text { The analytical group } & \text { The comprehensive group } \\
\text { improved more in their } & \text { improved more in their } \\
\text { playing capacity } & \text { playing capacity } \\
\end{array}$ & \multirow[t]{2}{*}{ This variable was not contemplated in the research } & \multirow[t]{2}{*}{$\begin{array}{l}\text { There were no differences between } \\
\text { groups in game development }\end{array}$} \\
\hline & Both groups improved significantly & & \\
\hline $\begin{array}{c}\text { Affectivity, } \\
\text { enjoyment and } \\
\text { motivation }\end{array}$ & $\begin{array}{l}\text { The analytical method may have provoked some lacks in } \\
\text { motivation, though this was not shown empirically }\end{array}$ & $\begin{array}{l}\text { Whole instruction generated greater security and } \\
\text { satisfaction among the subjects }\end{array}$ & $\begin{array}{l}\text { This variable was not contemplated } \\
\text { in the research }\end{array}$ \\
\hline $\begin{array}{l}\text { Behavior of the } \\
\text { instructor }\end{array}$ & $\begin{array}{l}\text { Suggests using the whole-part-whole method. } \\
\text { This variable was not contemplated in the research }\end{array}$ & $\begin{array}{l}\text { The comprehensive instructor motivated more, while the } \\
\text { other spent more time informing as to how to organize } \\
\text { the class and the material and giving a greater amount } \\
\text { of feedback to small groups or individuals }\end{array}$ & $\begin{array}{l}\text { This variable was not contemplated } \\
\text { in the research }\end{array}$ \\
\hline
\end{tabular}


Méndez, A.; Valero, A.; Casey, A. (2010). What are we being told about how to teach games? A threedimensional analysis of comparative research into different instructional studies in Physical Education and School Sports. Revista Internacional de Ciencias del Deporte. 18(6), 37-56.

http://www.cafyd.com/REVISTA/01803.pdf

\section{Instructional techniques}

Research into the efficacy of part-task vs. whole-task teaching methods in sports instruction led to the comparison of teaching techniques (Emmanouel, Zervas, \& Vagenas, 1992; Gabriele \& Maxwell, 1995; and Méndez, 1999). Unfortunately, we only have four studies at our disposal to establish comparisons, published in three different papers (see Table II). Moreover, the contents are disparate and one of these reports (Gabrielle \& Maxwell, 1995) is an abstract, and hence is lacking in data. Nevertheless, both the number of subjects per study and the duration of the treatments are higher that in the previous section, and hence the results may be more conclusive.

The studies by Enmanouel et al. (1992) and Méndez (1999) report that, in contrast with what the traditional beliefs uphold, direct technique is not the most efficient way of improving the technical skills of children and teenagers. In the former study, the combined technique improved motor skills more than the other techniques. In the latter study carried out by Méndez (1999), which focused on the teaching of basketball, the combined and indirect techniques were also found to be more effective in a dribbling test. This finding might be explained by the passive attitude that the direct technique children adopted with respect to the teacher's explanations and demonstrations and by the repetition of a series of drills out of the context. The proposal of play activities to bring about motivation might be more in consonance with the interests of children and may even have provoked the improvement in technique without its explicit instruction (Méndez, 1999).

As regards performance in the practice of the game, the indirect technique (Gabriele \& Maxwell, 1995) and the combined technique (see the second study on basketball in Méndez, 1999) appeared to improve decision taking especially in defensive actions.

On the other hand, a certain degree of consensus exists in pointing out the advantages of the indirect or investigation technique versus the direct technique with respect to the affectivemotivational and social variables, for example in the children's self-concept (Enmanouel et al., 1992), and in their assessment of the classes, of the subject and of enjoyment (Méndez, 1999).

In conclusion, these results support the notion that the adequate combination of both techniques (laying more emphasis on play activities that induce inquiry while lending momentary importance to information via direct instruction and to the repetition of exercises) may be advantageous, in general, for the teaching of sports games. 
Méndez, A.; Valero, A.; Ashley, C. (2010). What are we being told about how to teach games? A three-dimensional analysis of comparative research into different instructional studies in Physical Education and School Sports. Revista Internacional de Ciencias del Deporte. 18(6), 37-56. http://www.cafyd.com/REVISTA/01803.pdf

Table II. Comparison of Research Studies as a Function of the Instructional Technique.

\begin{tabular}{|c|c|c|c|c|}
\hline \multirow{3}{*}{$\begin{array}{c}\begin{array}{c}\text { Direct vs. indirect } \\
\text { instruction }\end{array} \\
\text { Nature of the research }\end{array}$} & \multirow[b]{2}{*}{ Emmanouel et al. (1992) } & \multirow[b]{2}{*}{ Gabriele and Maxwell (1995) } & \multirow{2}{*}{\multicolumn{2}{|c|}{ Méndez (1999) }} \\
\hline & & & & \\
\hline & $\begin{array}{c}\text { Comparison of four instruction methods: } \\
\text { direct, indirect, combined and focused on the } \\
\text { playing of the sport }\end{array}$ & $\begin{array}{c}\text { Comparison of a direct method versus an } \\
\text { indirect method }\end{array}$ & \multicolumn{2}{|c|}{$\begin{array}{c}\text { Comparison of three instruction techniques: one, indirect } \\
\text { instruction, another, search and a third based on the } \\
\text { combination of both }\end{array}$} \\
\hline Sport & Multi-sport initiation & Squash & Skating floorball & Basketball \\
\hline Context & Physical Education & University & Physical Education & Physical Education \\
\hline Age & 10 year olds & Over 18 year olds & $14-15$ year olds & 13-14 year olds \\
\hline Gender & Males and females & Males and females & Males and females & Males and females \\
\hline $\begin{array}{l}\text { No. of sessionsl } \\
\text { Frequency }\end{array}$ & $\begin{array}{c}60 \\
3 \text { per week } \\
\end{array}$ & $\begin{array}{c}6 \text { weeks } \\
\text { Not specified }\end{array}$ & $\begin{array}{c}15 \\
2 \text { per week }\end{array}$ & $\begin{array}{c}10 \\
2 \text { per week }\end{array}$ \\
\hline $\begin{array}{l}\text { Duration of the } \\
\text { session }\end{array}$ & $\begin{array}{c}\text { Not specified, though } 60 \text { minutes is } \\
\text { understood }\end{array}$ & Not specified & 50 minutes & 50 minutes \\
\hline $\begin{array}{l}\text { No. of groups and } \\
\text { subjects per group }\end{array}$ & $\begin{array}{l}4 \text { experimental groups: } 102 \text { subjects } \\
1 \text { control group: } 28 \text { subjects }\end{array}$ & 2 groups, the number is not specified & 3 groups of 25 subjects & 3 groups of 24 subjects \\
\hline Total no. of sessions & 130 & Not specified & 75 & 72 \\
\hline Technical skills & $\begin{array}{l}\text { The combined method was the most effective } \\
\text { in improving motor abilities }\end{array}$ & $\begin{array}{l}\text { Both methods improved the subjects' skills } \\
\text { and showed a similar capacity of execution }\end{array}$ & $\begin{array}{l}\text { There were no differences } \\
\text { between groups }\end{array}$ & $\begin{array}{c}\text { The direct group was not as } \\
\text { effective in the dribbling test as } \\
\text { the other two groups }\end{array}$ \\
\hline $\begin{array}{l}\text { Knowledge } \\
\text { acquisition }\end{array}$ & $\begin{array}{l}\text { This variable was not contemplated in the } \\
\text { research }\end{array}$ & $\begin{array}{l}\text { This variable was not contemplated in the } \\
\text { research }\end{array}$ & Not evaluated & $\begin{array}{c}\text { The combined group obtained } \\
\text { better results in declarative } \\
\text { knowledge }\end{array}$ \\
\hline $\begin{array}{l}\text { Performance in the } \\
\text { practice of the game }\end{array}$ & $\begin{array}{l}\text { This variable was not contemplated in the } \\
\text { research }\end{array}$ & $\begin{array}{c}\text { The indirect method led to a greater } \\
\text { number of correct decisions, as well as a } \\
\text { better selection of skills }\end{array}$ & $\begin{array}{l}\text { There were no differences } \\
\text { between groups }\end{array}$ & $\begin{array}{l}\text { The combined group improved in } \\
\text { decision taking and execution of } \\
\text { defending the player without the } \\
\text { ball }\end{array}$ \\
\hline $\begin{array}{l}\text { Affectivity, enjoyment } \\
\text { and motivation }\end{array}$ & $\begin{array}{l}\text { The direct method was the most effective in } \\
\text { improving the subjects' self-concept, while the } \\
\text { method focused on the playing of the sport } \\
\text { was the one that obtained the best results in } \\
\text { social attitudes }\end{array}$ & $\begin{array}{l}\text { This variable was not contemplated in the } \\
\text { research }\end{array}$ & $\begin{array}{l}\text { The search and combined } \\
\text { group were more satisfied } \\
\text { with the classes, the sport } \\
\text { and the idea of continuing } \\
\text { practicing }\end{array}$ & $\begin{array}{l}\text { The search group afforded more } \\
\text { value to Physical Education, the } \\
\text { degree of enjoyment and the } \\
\text { classes received }\end{array}$ \\
\hline $\begin{array}{l}\text { Behavior of the } \\
\text { instructor }\end{array}$ & $\begin{array}{l}\text { This variable was not contemplated in the } \\
\text { research }\end{array}$ & $\begin{array}{l}\text { This variable was not contemplated in the } \\
\text { research }\end{array}$ & $\begin{array}{c}\text { This variable was not } \\
\text { contemplated in the } \\
\text { research }\end{array}$ & $\begin{array}{l}\text { The time devoted to the task was } \\
\text { greater in the search and } \\
\text { combined groups }\end{array}$ \\
\hline
\end{tabular}


Méndez, A.; Valero, A.; Casey, A. (2010). What are we being told about how to teach games? A threedimensional analysis of comparative research into different instructional studies in Physical Education and School Sports. Revista Internacional de Ciencias del Deporte. 18(6), 37-56.

http://www.cafyd.com/REVISTA/01803.pdf

\section{Instructional approaches in sports initiation}

It is within this dimension that the majority of research is to be found, which focuses on discerning which approach is the most effective in the child's initiation to sport, especially in the learning of a series of skills, in the acquisition of a certain knowledge of tactics and its application to the real game situation (see Table III).

In contrast to the studies carried out and reported in the previous two sections, here we find that the context of application is not purely educational in training centers such as Primary, Secondary or even University Education, but extends to Sports Schools (French, Werner, Rink et al., 1996; French, Werner, Taylor et al., 1996; McPherson \& French, 1991; Rink, French, \& Werner, 1991; Turner, 1992; Turner \& Martinek, 1992, 1999). The sports dealt with range from a divided court (volleyball) and racket (badminton and tennis) games to invasion sports such as field hockey, soccer, basketball and handball.

The age range that the majority of studies on sports instructional approaches have focused on is situated between 11 and 13 years of age, although other authors employed samples of 8 to 9 year olds (Allison \& Thorpe, 1997), secondary school pupils from 14 to 15 years of age (French, Werner, Rink et al., 1996; French, Werner, Taylor et al., 1996; Rink et al. 1991), and university students of between 19 and 22 years of age (McPherson \& French, 1991; Romero, 2001). The number of sessions employed in the treatment of the studies varies from one study to another, the minimum duration being six sessions (Allison \& Thorpe, 1997; Lawton, 1989; Turner, 1992; Turner \& Martinek, 1992), the maximum 38-40 (García, 2001; McPherson \& French, 1991), with an average duration of sessions of between 9 and 16 sessions. Differences may be established in the weekly frequency of sports instruction, distinguishing between one and two weekly sessions in the subject of Physical Education within the school context and one to five sessions a week in Sports Schools, which indicates that there is greater divergence in the latter. Likewise, we also find differences with regards to sample size. The size of the groups in the studies conducted during school time (the subject of Physical Education) ranging between 16 subjects per group in Lawton (1989) and 29 in Mitchell, Griffin and Oslin (1995), whereas in extramural instruction (Sports Schools), the number ranged between 12 in Rink et al. (1991) and French, Werner, Rink et al. (1996), to 30 subjects per group in Turner (1992) or Turner and Martinek (1992).

As regards the dependent variables, the majority of studies coincide in not finding differences in the efficacy of technical skills between groups, either due to the fact that both groups improved similarly (Allison \& Thorpe, 1997; French, Werner, Taylor et al., 1996), or that a significant progression was not found in either group (French, Werner, Rink et al., 1996; García, 2001; Griffin et al., 1995; Lawton, 1989; Mitchell et al., 1995; Rink et al., 1991; Romero, 2001; Turner, 1992; Turner \& Martinek, 1992; Turner, 1996). The remaining studies present contradictory results, as is the case of McPherson and French (1991), who state that the tactics-based group achieved an improvement with respect to the skills-based group, while Turner and Martinek (1999) report that the skills-based group improved with respect to the control group in the skills test.

The acquisition of knowledge is one of the dependent variables that acquires more importance with the new methodological approaches. There are numerous studies that corroborate that a greater degree of comprehension is acquired through the tactics-based approaches, as is the case of Allison and Thorpe (1997), García (2001), Griffin et al. (1995), McPherson and French (1991), Mitchell et al. (1995), Turner (1996) and Turner and Martinek (1999). However, clear-cut results were not obtained with regards to the application of this knowledge 
Méndez, A.; Valero, A.; Casey, A. (2010). What are we being told about how to teach games? A threedimensional analysis of comparative research into different instructional studies in Physical Education and School Sports. Revista Internacional de Ciencias del Deporte. 18(6), 37-56.

http://www.cafyd.com/REVISTA/01803.pdf

to game situations and especially during decision taking. Half the studies that took this variable into consideration conclude that advances are produced with the tactics-based approaches, versus the other half that suggest the contrary.

Other variables considered in the analyses, though not in all the studies, were motivation, enjoyment and affectivity. The majority of the research studies confirmed that the tacticsbased approaches generates more affective behavior and declarations and leads to more enjoyable practice sessions (Allison \& Thorpe, 1997; Griffin et al., 1995; Mitchell et al., 1995; Romero, 2001; Turner, 1996). These findings were explained by Holt et al. (2002) in the sense that games are more fun than drills for children in organized sport practice environments.

Finally the only variable that we found that was not pupil-centred, and which we have called 'the behavior of the teacher' was only taken into account in 2 of the 12 studies. Allison and Thorpe (1997) found that the teacher has more opportunities to observe and evaluate with the tactics-based approaches. In other study, Wright, McNeill, Fry \& Wang (2005) concluded that tactics-based participants (physical education teacher education students) were unanimous in their choice of tactical lesson plans for their module assignment, whereas $80 \%(n=15)$ of the skills-based group also chose tactical lesson plans. When providing their rationale(s) for choosing tactical plans, the most popular reasons were: engaging pupils cognitively; stimulating pupil interest; allowing for more game play; and providing pupils the opportunity to transfer concepts from one game to another. 
Méndez, A.; Valero, A.; Ashley, C. (2010). What are we being told about how to teach games? A three-dimensional analysis of comparative research into different instructional studies in Physical Education and School Sports. Revista Internacional de Ciencias del Deporte. 18(6), 37-56. http://www.cafyd.com/REVISTA/01803.pdf

Table III. Comparison of Research Studies as a Function of the Sports Instructional Approaches (Table continues).

Technical vs. alternative

\section{Nature of the research}

Lawton (1989)

Comparison of the tactics-based approach versus a skills-based approach

\begin{tabular}{c}
\hline Sport \\
\hline Context \\
\hline Age \\
\hline Gender \\
\hline $\begin{array}{c}\text { No. of sessionsl } \\
\text { Frequency }\end{array}$ \\
\hline Duration of the session \\
\hline No. of groups and
\end{tabular}

\begin{tabular}{c}
\hline $\begin{array}{c}\text { No. of groups and } \\
\text { subjects per group }\end{array}$ \\
\hline Total no. of sessions \\
\hline Technical skills
\end{tabular}

\begin{abstract}
1 tactics-based group: 16 subjects
1 skills-based group: 16 subjects

1 control group: 16 subjects
\end{abstract}

\section{McPherson and French (1991)}

Comparison of technical instruction with strategic elements versus tactics instruction with technical elements with technical elem

\begin{tabular}{cc} 
Badminton & with technical elements \\
\hline Physical Education & Sports School \\
\hline $12-13$ year olds & $19-22$ year olds \\
\hline Males and females & Males and females \\
\hline
\end{tabular}

\section{Rink et al. (1991)}

French, Werner, Rink et al. (1996)

Comparison of tactics-based instruction, skills-based

Badminton

Sports School

14-15 year olds

Males and females

3 per week

60 minutes 50 minutes

1 technical instruction group: 16 subjects

1 tactics instruction group: 13 subjects

ales and females

\begin{tabular}{|c|c|c|c|}
\hline & $\begin{array}{c}\text { skills } \\
\end{array}$ & group & technical components \\
\hline Knowledge acquisition & $\begin{array}{l}\text { There were no significant differences in the } \\
\text { level of improvement of the subjects in } \\
\text { understanding of the tactics bases }\end{array}$ & $\begin{array}{l}\text { The strategic group focused attention more on } \\
\text { decision-taking (declarative and procedural } \\
\text { knowledge) }\end{array}$ & No differences were found between groups \\
\hline $\begin{array}{l}\text { Performance in the } \\
\text { practice of the game }\end{array}$ & $\begin{array}{l}\text { This variable was not contemplated in the } \\
\text { research }\end{array}$ & $\begin{array}{l}\text { The execution component was improved by } \\
\text { both forms of instruction, although the tactics- } \\
\text { based group only improved when the skill was } \\
\text { integrated }\end{array}$ & $\begin{array}{l}\text { The three groups obtained improved performances in the } \\
\text { components of decision taking compared to the control } \\
\text { group }\end{array}$ \\
\hline $\begin{array}{l}\text { Affectivity, enjoyment and } \\
\text { motivation }\end{array}$ & $\begin{array}{l}\text { Significant differences were not found among } \\
\text { the results for affectivity after practice }\end{array}$ & $\begin{array}{l}\text { This variable was not contemplated in the } \\
\text { research }\end{array}$ & $\begin{array}{c}\text { The control group made more affective declarations and } \\
\text { were more cooperative than the experimental groups }\end{array}$ \\
\hline Behavior of the instructor & $\begin{array}{l}\text { This variable was not contemplated in the } \\
\text { research }\end{array}$ & $\begin{array}{l}\text { This variable was not contemplated in the } \\
\text { research }\end{array}$ & This variable was not contemplated in the research \\
\hline
\end{tabular}


Méndez, A.: Valero, A.; Ashley, C. (2010). What are we being told about how to teach games? A three-dimensional analysis of comparative research into different instructional studies in Physical Education and School Sports. Revista Internacional de Ciencias del Deporte. 18(6), 37-56. http://www.cafyd.com/REVISTA/01803.pdf

Table III. Comparison of Research Studies as a Function of the Sports Instructional Approaches (Table continues).

\begin{tabular}{|c|c|c|c|}
\hline $\begin{array}{l}\text { Technical vs. } \\
\text { alternative }\end{array}$ & $\begin{array}{c}\text { Turner (1992) } \\
\text { Turner and Martinek (1992) }\end{array}$ & $\begin{array}{l}\text { Turner and Martinek (1995) } \\
\text { Turner and Martinek (1999) }\end{array}$ & Griffin et al. (1995) \\
\hline $\begin{array}{l}\text { Nature of the } \\
\text { research }\end{array}$ & $\begin{array}{c}\text { Comparison of a technical approach versus a } \\
\text { game-based approach }\end{array}$ & $\begin{array}{c}\text { Comparison of the game-based approach versus a } \\
\text { skills-based approach }\end{array}$ & $\begin{array}{c}\text { Comparison of a tactics-based approach versus a } \\
\text { skills-based approach }\end{array}$ \\
\hline Sport & Field hockey & Field hockey & Volleyball \\
\hline Context & Sports School & Sports School & Physical Education \\
\hline Age & $12-13$ year olds & $12-13$ year olds & $11-12$ year olds \\
\hline Gender & Males and females & Males and females & Males and females \\
\hline $\begin{array}{l}\text { No. of sessionsl } \\
\text { Frequency }\end{array}$ & $\begin{array}{c}6 \\
1 \text { per week } \\
\end{array}$ & 15 & 9 \\
\hline $\begin{array}{l}\text { Duration of the } \\
\text { session }\end{array}$ & 35 minutes & 45 minutes & Not specified, though 60 minutes is understood \\
\hline $\begin{array}{l}\text { No. of sessions and } \\
\text { subjects per group }\end{array}$ & 4 experimental groups of 11 subjects & $\begin{array}{l}3 \text { game-based groups } \\
3 \text { technical groups } \\
1 \text { control group }\end{array}$ & $\begin{array}{l}1 \text { tactics-based group: } 22 \text { subjects } \\
1 \text { skills group: } 21 \text { subjects }\end{array}$ \\
\hline Total no. of sessions & 44 & 71 & 43 \\
\hline Technical skills & No differences were found between groups & $\begin{array}{l}\text { The technical group was faster than the control group } \\
\text { in the skills test }\end{array}$ & $\begin{array}{l}\text { There was no significant improvement in skills in } \\
\text { any group }\end{array}$ \\
\hline $\begin{array}{l}\text { Knowledge } \\
\text { acquisition }\end{array}$ & $\begin{array}{c}\text { Differences were not found among groups in the } \\
\text { acquisition of both declarative and procedural } \\
\text { knowledge }\end{array}$ & $\begin{array}{l}\text { The game-based group presented greater declarative } \\
\text { and procedural knowledge than the control group }\end{array}$ & $\begin{array}{c}\text { Both groups improved their knowledge with respect } \\
\text { to skills and tactics, the tactics-based approach } \\
\text { being significantly better than the skills-based } \\
\text { approach }\end{array}$ \\
\hline $\begin{array}{l}\text { Performance in the } \\
\text { practice of the game }\end{array}$ & $\begin{array}{l}\text { Differences were not found in capacity when } \\
\text { practicing the game }\end{array}$ & $\begin{array}{l}\text { The game-based group showed better decision taking } \\
\text { in passing, as well as better execution in controlling } \\
\text { and passing the ball than the other two groups }\end{array}$ & $\begin{array}{c}\text { The tactics-based group was more efficient with } \\
\text { respect to position on the court and decision } \\
\text { making }\end{array}$ \\
\hline $\begin{array}{l}\text { Affectivity, enjoyment } \\
\text { and motivation }\end{array}$ & This variable was not contemplated in the research & This variable was not contemplated in the research & $\begin{array}{c}\text { The tactical approach provided greater interest and } \\
\text { enjoyment }\end{array}$ \\
\hline $\begin{array}{l}\text { Behavior of the } \\
\text { instructor }\end{array}$ & This variable was not contemplated in the research & This variable was not contemplated in the research & This variable was not contemplated in the research \\
\hline
\end{tabular}


Méndez, A.: Valero, A.; Ashley, C. (2010). What are we being told about how to teach games? A three-dimensional analysis of comparative research into different instructional studies in Physical Education and School Sports. Revista Internacional de Ciencias del Deporte. 18(6), 37-56. http://www.cafyd.com/REVISTA/01803.pdf

Table III. Comparison of the Research as a Function of the Sports Instructional Approaches (Table continues).

\begin{tabular}{|c|c|c|c|}
\hline $\begin{array}{l}\text { Technical vs. } \\
\text { alternative }\end{array}$ & Mitchell et al. (1995) & French, Werner, Taylor et al. (1996) & $\begin{array}{l}\text { Turner (1993) } \\
\text { Turner (1996) }\end{array}$ \\
\hline $\begin{array}{l}\text { Nature of the } \\
\text { research }\end{array}$ & $\begin{array}{l}\text { Comparison of the efficacy of tactics-based } \\
\text { versus skills-based approaches }\end{array}$ & $\begin{array}{l}\text { Comparison of tactics-based instruction, skill-based } \\
\text { instruction and instruction based on the combination } \\
\text { of both }\end{array}$ & $\begin{array}{l}\text { Comparison of an game-based approach versus a } \\
\text { technical approach to instruction }\end{array}$ \\
\hline Sport & Soccer & $\begin{array}{l}\text { Badminton } \\
\end{array}$ & Field hockey \\
\hline Context & Physical Education & Sports School & Physical Education \\
\hline Age & $11-12$ year olds & 14-15 year olds & $12-13$ year olds \\
\hline Gender & Males and females & Males and females & Males and females \\
\hline $\begin{array}{l}\text { No. of sessionsl } \\
\text { Frequency }\end{array}$ & 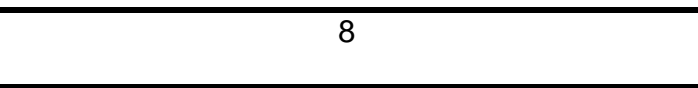 & $\begin{array}{c}30 \\
5 \text { per week }\end{array}$ & 16 \\
\hline $\begin{array}{c}\text { Duration of the } \\
\text { session }\end{array}$ & Not specified, though 60 minutes is understood & 45 minutes & 45 minutes \\
\hline $\begin{array}{l}\text { No. of groups and } \\
\text { subjects per group }\end{array}$ & $\begin{array}{c}1 \text { tactical group of } 24 \text { subjects } \\
1 \text { skills-based group of } 29 \text { subjects }\end{array}$ & $\begin{array}{l}3 \text { experimental groups of } 13 \text { subjects } \\
1 \text { control group of } 13 \text { subjects }\end{array}$ & $\begin{array}{c}4 \text { groups of } 12 \text { subjects } \\
2 \text { technical groups of } 12 \text { subjects } \\
2 \text { game-based groups of } 12 \text { subjects } \\
\end{array}$ \\
\hline Total no. of sessions & 53 & 52 & 48 \\
\hline Technical skills & No group improved with time & $\begin{array}{l}\text { All the groups acquired greater technical skills } \\
\text { compared to a control group }\end{array}$ & There were no differences between groups \\
\hline $\begin{array}{l}\text { Knowledge } \\
\text { acquisition }\end{array}$ & $\begin{array}{l}\text { Both groups improved their knowledge with } \\
\text { respect to skills, although only the tactical group } \\
\text { improved significantly in tactical knowledge }\end{array}$ & $\begin{array}{l}\text { All the experimental groups improved with respect to } \\
\text { the control group }\end{array}$ & $\begin{array}{l}\text { The game-based group improved in declarative } \\
\text { knowledge significantly more than the technical } \\
\text { group; such differences were not found in } \\
\text { procedural knowledge }\end{array}$ \\
\hline $\begin{array}{l}\text { Performance in the } \\
\text { practice of the game }\end{array}$ & $\begin{array}{l}\text { The tactical group was more efficient during } \\
\text { practice of the game, especially in movements } \\
\text { without the ball and in decision taking }\end{array}$ & $\begin{array}{l}\text { All the experimental groups improved, although the } \\
\text { tactics-based and skills-based groups performed } \\
\text { better than the combined group }\end{array}$ & $\begin{array}{l}\text { The game-based group improved significantly in } \\
\text { control and decision taking with respect to the } \\
\text { technical group, but not in execution }\end{array}$ \\
\hline $\begin{array}{l}\text { Affectivity, } \\
\text { enjoyment and } \\
\text { motivation }\end{array}$ & There were no differences between groups & $\begin{array}{c}\text { According to Tjeerdsma, Rink and Graham (1996), } \\
\text { a slight improvement in affectivity was observed in } \\
\text { the combined group with respect to the other two } \\
\text { groups }\end{array}$ & $\begin{array}{c}\text { The game-based approach provided greater } \\
\text { satisfaction and enjoyment than the technical } \\
\text { approach }\end{array}$ \\
\hline $\begin{array}{l}\text { Behavior of the } \\
\text { instructor }\end{array}$ & $\begin{array}{l}\text { This variable was not contemplated in the } \\
\text { research }\end{array}$ & This variable was not contemplated in the research & This variable was not contemplated in the research \\
\hline
\end{tabular}


Méndez, A.: Valero, A.; Ashley, C. (2010). What are we being told about how to teach games? A three-dimensional analysis of comparative research into different instructional studies in Physical Education and School Sports. Revista Internacional de Ciencias del Deporte. 18(6), 37-56. http://www.cafyd.com/REVISTA/01803.pdf

Table III. Comparison of the Research as a Function of the Sports Instructional Approaches (Table continues).

\begin{tabular}{|c|c|c|c|}
\hline $\begin{array}{l}\text { Technical vs. } \\
\text { alternative }\end{array}$ & Allison and Thorpe (1997) & Romero (2001) & $\begin{array}{c}\text { García (2001) } \\
\text { García and Ruiz (2003) } \\
\end{array}$ \\
\hline Nature of the research & $\begin{array}{l}\text { Comparison of the efficacy of skill-based instruction } \\
\text { and TGfU approach in the teaching of sports games }\end{array}$ & $\begin{array}{l}\text { Comparison of the skills-based and tactics-based } \\
\text { approaches }\end{array}$ & $\begin{array}{l}\text { Comparison of the skills-based approach } \\
\text { with the tactics-based approach }\end{array}$ \\
\hline Sport & Basketball & Volleyball & Handball \\
\hline Context & Physical Education & $\begin{array}{c}\text { Physical Education ( } 2^{\text {nd }} \text { Year at Teacher Training } \\
\text { College) }\end{array}$ & Sports School \\
\hline Age & 8 year olds & $20-22$ year olds & 10-11 year olds \\
\hline Gender & Females & Males and females & Males \\
\hline $\begin{array}{l}\text { No. of sessions } \\
\text { Frequency }\end{array}$ & $\begin{array}{c}6 \\
1 \text { per week }\end{array}$ & $\begin{array}{c}10 \\
2 \text { per week }\end{array}$ & $\begin{array}{l}40 \text { plus } 15 \text { games } \\
2 \text { per week }\end{array}$ \\
\hline $\begin{array}{l}\text { Duration of the } \\
\text { session }\end{array}$ & 60 minutes & 90 minutes & 60 minutos \\
\hline $\begin{array}{l}\text { No. of groups and } \\
\text { subjects per group }\end{array}$ & 2 groups of 28 subjects & $\begin{array}{c}2 \text { groups, } 48 \text { subjects in the skills-based group and } 42 \\
\text { in the tactics-based group }\end{array}$ & $\begin{array}{l}2 \text { groups, } 13 \text { subjects in the skills-based } \\
\text { group and } 14 \text { in the tactics-based group }\end{array}$ \\
\hline Total no. of sessions & 40 & 90 & 27 \\
\hline Technical skill & The skills level of all the groups improved & $\begin{array}{c}\text { The tactics-based group were better in all techniques } \\
\text { skills except in receiving }\end{array}$ & Significant differences were not found \\
\hline Knowledge acquisition & $\begin{array}{l}\text { The TGfU group showed a better appreciation of } \\
\text { when to pass, shoot or dribble }\end{array}$ & $\begin{array}{l}\text { No differences were found except between the } \\
\text { explanation-description of the skills-based approach } \\
\text { and the discussion work of the tactics-based approach }\end{array}$ & $\begin{array}{l}\text { The tactics-based group showed better } \\
\text { declarative knowledge }\end{array}$ \\
\hline $\begin{array}{l}\text { Performance in the } \\
\text { practice of the game }\end{array}$ & $\begin{array}{c}\text { The TGfY group were better in decision taking when } \\
\text { executing skills }\end{array}$ & $\begin{array}{l}\text { The tactics-based group were better in individual and } \\
\text { group efficacy and in decision taking }\end{array}$ & $\begin{array}{c}\text { The tactics-based group progressed more } \\
\text { in execution and in decision taking, } \\
\text { although the differences were not } \\
\text { significant }\end{array}$ \\
\hline $\begin{array}{l}\text { Affectivity, enjoyment } \\
\text { and motivation }\end{array}$ & $\begin{array}{l}\text { The skills-based approach generated low levels of } \\
\text { enjoyment, playing capacity and feelings towards } \\
\text { physical education in the less skilful, in contrast to the } \\
\text { TGfU approach }\end{array}$ & $\begin{array}{c}\text { Play was more fluid, creative and free in the tactics- } \\
\text { based group }\end{array}$ & $\begin{array}{l}\text { This variable was not contemplated in the } \\
\text { research }\end{array}$ \\
\hline $\begin{array}{l}\text { Behavior of the } \\
\text { instructor }\end{array}$ & $\begin{array}{l}\text { More opportunities to observe and evaluate with the } \\
\text { TGfU approach. The child becomes the focus of the } \\
\text { teaching-learning process }\end{array}$ & $\begin{array}{c}\text { The skills-based approach was characterized by a lack } \\
\text { of group work and scant participation. The tactics- } \\
\text { based approach was characterized by reflection, poor } \\
\text { warming-up and scant physical work }\end{array}$ & $\begin{array}{l}\text { This variable was not contemplated in the } \\
\text { research }\end{array}$ \\
\hline
\end{tabular}


Méndez, A.; Valero, A.; Casey, A. (2010). What are we being told about how to teach games? A threedimensional analysis of comparative research into different instructional studies in Physical Education and School Sports. Revista Internacional de Ciencias del Deporte. 18(6), 37-56.

\section{Conclusions}

Although there exist numerous studies on sports instruction aimed at comparing different methodologies in order to test which is the most appropriate in diverse contexts of application: physical education, extramural, club or sports school, it's not easy to compare them, and therefore we attempted to group them together according to the nature of the intervention and to analyze the three key methodological dimensions in the debate as identified by Gréhaigne et al. (1999): the part-task vs. whole-task teaching method, the instructional technique and the sports instructional model.

On the basis of the part-task vs. whole-task teaching method, it can be seen that whole sessions generate greater performance, satisfaction and security in pupils, in contrast to parttask learning, which present a greater sense of pupil frustration due to them not achieving the expected mastery of the sport. The remainder of the results obtained are inconclusive, possibly due to the reduced number of sessions employed in the interventions.

Focusing attention on the instructional technique, it appears that direct instruction is not necessarily the most effective way of improving technical skills, owing to the passive attitude generated in children as a result of both repeating a series of exercises without understanding their real meaning and the explanations and demonstrations of the teacher. The indirect and combined instruction have a positive influence in decision-taking and in the assessment that the subjects make of the activity at an affective and social level.

Finally, the majority of research studies have focused on comparing different approaches to sports instruction without there being consensus in the results obtained as regards the level of efficacy in technical skills or in the application of knowledge to real practice of the game. In contrast, for the variables of acquisition of knowledge and affectivity, enjoyment and motivation, many studies have coincided in reporting that greater understanding is acquired and more affective behavior and declarations are generated, thus leading to more enjoyable practice, via the tactics-based approaches.

These findings lead us to reconsider the use of the part-task teaching method, direct instruction and skills-based approach in sports instruction, and especially in the compulsory setting of physical education. Special attention needs to be paid to the relation that may exist between the positive effects at a social-affective and motivational level of the alternative models and the children's prolonged and healthy involvement in the practicing of sports. Nevertheless, we believe that further longitudinal studies comparing both approaches are needed that focus on the transference between diverse sports modalities belonging the same tactics family, employing research designs and variables that enable comparison of the results obtained with those existing at the present time.

Since Rink et al's (1996) review, a great deal has been written about comparing technical and tactical approaches to teaching games, or examine each approach independently. Holt et al. (2002) and Rink (2001) argued that research should move beyond the debate about which is better and focus on that which occurs in the teaching/learning processes of these approaches. Nevertheless, in spite of the recent writings in journals and three international conferences devoted to TGfU related approaches to date, there remains some resistance among field teachers and practitioners (McNeill, Fry, Wright, Tan, Tan \& Schempp, 2004). Thus, as Curtner-Smith et al., (2005), Kirk (2005) and Metzler (2005) observe, despite several significant changes to physical education, teachers continue to use only one or two ways to teach, the most common of which is the direct instruction. Thus, these studies reveal that 
Méndez, A.; Valero, A.; Casey, A. (2010). What are we being told about how to teach games? A threedimensional analysis of comparative research into different instructional studies in Physical Education and School Sports. Revista Internacional de Ciencias del Deporte. 18(6), 37-56.

http://www.cafyd.com/REVISTA/01803.pdf

teachers use the same limited number of teaching methods irrespective of the content, the learning outcomes they hope to achieve, and an analysis of their students' readiness to learn.

In our opinion, if we are looking for a change in teachers' practices, research evidence of comparative studies must give them good reasons for making this effort of change or diversify their practice. Results from early research studies have not been as conclusive as they might due to conceptual and methodological problems that are now beginning to be resolved (Kirk, 2001). The three-dimensional review reported in this paper could be used as complementary research to aid in future longitudinal studies such as the investigation that look at the integration of diverse instructional studies (Hastie \& Curtner-Smith, 2006); $\rightarrow$ sustituir por coma the more programmatic research suggested by Griffin, Brooker and Patton (2005) which could be grounded in three theoretical frameworks: achievement goal theory, information processing and situated learning theory. Of course, as Griffin \& Patton (2005) suggest, the research on games teaching must evolve and explore new avenues of study, but in our opinion this could be better achieved without excluding comparative studies.

\section{References}

Allison, S. \& Thorpe, R. (1997). A comparison of the effectiveness of two approaches to teaching games within physical education. A Skills approach versus a Games for Understanding approach. The British J ournal of Physical Education, 28(3), 9-13.

Australian Sports Commission (1997). Game sense: Developing thinking players. Belconnen: ASC.

Butler, J.; Griffin, L.; Lombardo, B.; Nastasi, R., \& Robson, C. (2003), Reflections and Projections. Chapter 18. In Butler, J; Griffin, LL, Lombardero, B. \& Nastasi, R. Teaching games for understanding in Physical Education and Sport (pp.213-222). Reston, VA. National Association for Sport and Physical Education.

Blomqvist, M.; Luhtanen, P., \& Laakso, L. (2001). Comparison of two types of instruction in badminton. European J ournal of Physical Education, 6(2), 139-155.

Boutmans, J. (1983). Comparative effectiveness of two methods of teaching team sports in secondary schools. Paper from the International Congress Teaching Team Sports (pp.239-247). AIESEP: Roma.

Bunker, D. \& Thorpe, R. (1982). A model for the teaching of games in secondary schools. The Bulletin of Physical Education, 18(1), 5-8.

Casey, A. (2006, September). From Highwayman to Highway Patrol: A Physical Education Teacher's Journey towards Student-Centred Instruction. Paper presented at the British Education Research Association National Conference, Warwick, UK.

Curtner-Smith, M.; Todorovich, J.R.; McCaughtry, N, A., \& Lacon, S.A. (2001). Urban teachers' use of productive and reproductive teaching styles within the confines of the National Curriculum for Physical Education. European Physical Education Review, 7, 177-190

Durán, C. \& Lasierra, G. (1987). Estudio experimental sobre didáctica aplicada a la iniciación de los deportes colectivos. (An experimental study on teaching applied to initiation in team sports.) Revista de Investigación y Documentación sobre las Ciencias de la Educación Física y del Deporte, 7, 91-128.

Emmanouel, C.; Zervas, Y., \& Vagenas G. (1992). Effects of four physical education teaching methods on development of motor skill, self-concept, and social attitudes of fifth-grade children. Perceptual Motor Skills, 74(2), 1151-1167. 
Méndez, A.; Valero, A.; Casey, A. (2010). What are we being told about how to teach games? A threedimensional analysis of comparative research into different instructional studies in Physical Education and School Sports. Revista Internacional de Ciencias del Deporte. 18(6), 37-56.

http://www.cafyd.com/REVISTA/01803.pdf

French, K.E.; Werner, P.H.; Rink, J.E.; Taylor, K., \& Hussey, K. (1996). The effects of a 3-week unit of tactical, skill, or combined tactical and skill instruction on badminton performance of ninth-grade students. Journal of Teaching in Physical Education, 15 (4), 418-438.

French, K.E.; Werner, P.H.; Taylor, K.; Hussey, K., \& Jones, K. (1996). The effects of a 6 -week unit of tactical, skill, or combined tactical and skill instruction on badminton performance of ninth-grade students. Journal of Teaching in Physical Education, 15(4), 439-463.

Gabriele, T.E. \& Maxwell, T. (1995). Direct versus indirect methods of squash instruction. Research Quarterly for Exercise and Sport. 66. Supplement. A - 63.

García, J. A. (2001). Adquisición de la competencia para el deporte en la infancia: el papel del conocimiento y la comprensión en la toma de decisiones en balonmano. (Acquisition of sports competence in childhood: the role of knowledge and understanding in decision taking in handball.) Unpublished PhD Thesis, Universidad de Extremadura, Facultad de Ciencias del Deporte de Cáceres.

García, J. A. \& Ruiz, L. M. (2003). Análisis comparativo de dos modelos de intervención en el aprendizaje del balonmano. (Comparative analysis of two models of intervention in the learning of handball.) Revista de Psicología del Deporte, 12(1) 55-66.

Gréhaigne, J.-F.; Godbout, P., \& Bouthier, D. (1999). The foundations of tactics and strategy in team sports. Journal of Teaching in Physical Education, 18(2), 159174.Gréhaigne, J.F., Wallian, N., \& Godbout, P.(2005). Approche technologique et modélisation didactique des sports collectifs à l'école. I mpulsion, 4, 59-79.

Griffin, L.L.; Oslin, J.L., \& Mitchell, S.A. (1995). An analysis of two instructional approaches to teaching net games. Research Quarterly for Exercise and Sport. 66. Supplement. A - 64.

Griffin, L.L.; Brooker, R., \& Patton, K. (2005).Working towards legitimacy: two decades of teaching games for understanding, Physical Education, Sport Pedagogy, 10 (3), 213-223.

Griffin, L.L.; Mitchell, S.A., \& Oslin, J.L. (1997). Teaching sport concepts and skillls. A tactical games approach. Champaign, IL: Human Kinetics.

Griffin, L.L. \& Patton K. (2005) Chapter 1. Two Decades of Teaching Games for Understanding: Looking at the Past, Present, and Future. In Griffin, L., \& Butler, J. (Eds.). (2005). Teaching Games for Understanding: Theory, Research, and Practice. Champaign, IL: Human Kinetics.

Hastie, P.A. \& Curtner-Smith, M.D. (2006). Influence of a hybrid Sport EducationTeaching Games for Understanding unit on one teacher and his students. Physical Education and Sport Pedagogy. 11, (1),1-27.

Hardman, K. \& Marshall, J. (2005). Physical Education in Schools in European Context: Charter Principles, Promises and Implementation Realities. In Green, K. and Hardman, K. (Eds.) Physical Education: Essential Issues (pp. 39-64). London: Sage.

Holt, N. L.; Strean, W.B., \& García, E. (2002). Expanding the Teaching Games for Understanding Model: New avenues for future research and practice. Journal of Teaching in Physical Education, 21, 162-176.

Hopper, T. (2002). Teaching Games for Understanding. The importance of student emphasis over content emphasis JOPERD, 7 (7), 44-48.

Kirk, D. (2001, August). Future prospects and directions for TGfU. Paper presented at International Conference: Teaching for Understanding in Physical Education and Sport, New Hampshire, USA. 
Méndez, A.; Valero, A.; Casey, A. (2010). What are we being told about how to teach games? A threedimensional analysis of comparative research into different instructional studies in Physical Education and School Sports. Revista Internacional de Ciencias del Deporte. 18(6), 37-56.

http://www.cafyd.com/REVISTA/01803.pdf

Kirk, D. (2005). Model-based teaching and assessment in physical education: The Tactical Games model. In Green, K. and Hardman, K. (Eds.) Physical Education: Essential Issues (pp. 128-142). London: Sage.

Kirk, D. \& MacPhail, A. (2002). "Teaching Games for Understanding and Situated Learning: Rethinking the Bunker-Thorpe Model". Journal of Teaching in Physical Education, 21(4), 177-179

Lawton, J. (1989). Comparison of two teaching methods in games. The Bulletin of Physical Education, 25(1), 35-38.

McMorris, T. (1988). "Comparison of effectiveness of two methods of teaching passing and support in football". In J. Durán, L.L. Hernández, \& L.M. Ruíz (Eds.). Paper from the World Congress Humanismo y nuevas tecnologías en la Educación Física y el Deporte (pp. 229-232). Madrid: AIESEP, MEC e INEF.

McMorris, T. (1998). Teaching Games for Understanding: Its contribution to the knowledge of skill acquisition from a motor learning perspective. European J ournal of Physical Education, 3(1), 65-74.

McNeill, M. C.; Fry, J. M.; Wright, S. C.; Tan, W. C.; Tan, K. S., \& Schempp, P. G. (2004) 'In the local context': Singaporean challenges to teaching games on practicum, Sport, Education and Society, 9, 3-32.

McPherson, S.L. \& French, K.E. (1991). Changes in cognitive strategies and motor skill in tennis. Journal of Sport \& Exercise Psychology, 13(1), 26-41.

Méndez, A. (1999). Análisis comparativo de las técnicas de enseñanza en la iniciación a dos deportes de invasión: el floorball patines y el baloncesto. (Comparative analysis of teaching techniques in the initiation to two invasion sports; skating floorball and basketball.) PhD Thesis. Universidad de Granada.

Metzler, P. (1986). Analysis of a mastery learning/personalized system of instruction for teaching tennis. In M. Pierón, \& G. Graham. The 1984 Olympic Scientific Congress Proceedings. Volume 6. Sport Pedagogy. Champaign, IL: Human Kinetics.

Metzler, M.W. (2005). Instructional Models for Physical Education. Scottsdale, Arizona: Holcomb Hathaway, Publishers. $2^{\text {nd }}$ ed.

Mitchell, S.A.; Griffin, L.L., \& Oslin, J.L. (1995). An Analysis of two instructional approaches to teaching invasion games. Research Quarterly for Exercise and Sport. 66 (Suppl) A-65.

Mosston, M. \& Ashworth, S. (1986). Teaching physical education (3rd. Ed.). New York: Merrill Macmillan Publishing.

Oslin, J.L. \& Mitchell, S.A. (1998). The Game Performance Assessment Instrument (GPAI): Development and Preliminary Validation. Journal of Teaching in Physical Education, 17, 231-243.

Rink, J.E. (2001). Investigation the assumptions of pedagogy. Journal of Teaching in Physical Education, 20, 112-128.

Rink, J. E.; French, K. E., \& Tjeerdsma, B. L. (1996). Foundations for the learning and instruction of sports and games, Journal of Teaching in Physical Education, 15, 399417.

Rink, J.E.; French, K.E., \& Werner, P. (1991). Tactical awareness as the focus for ninth grade badminton. Paper from the World Congress of Atlanta. Georgia: AlESEP.

Romero, S. (2001). Formación deportiva: nuevos retos en Educación. (Sports training; new challenges in Education.) Sevilla: Secretariado de Publicaciones de la Universidad de Sevilla. 
Méndez, A.; Valero, A.; Casey, A. (2010). What are we being told about how to teach games? A threedimensional analysis of comparative research into different instructional studies in Physical Education and School Sports. Revista Internacional de Ciencias del Deporte. 18(6), 37-56.

http://www.cafyd.com/REVISTA/01803.pdf

Tannehill, D. \& Lund, J. (2005). Building a Quality Physical Edcuation Program. In J. Lund \& D. Tannehill (Eds), Standards-Based Physical Education Curriculum Development (pp. 17-45). Sudbury: Jones and Bartlett.

Thorpe, R.; Bunker, D., \& Almond, L. (1986). Rethinking games teaching. Loughborough: University of Technology. Department of Physical Education and Sport Science.

Tjeerdsma, B.L.; Rink, J.E., \& Graham, K.C. (1996). Student perceptions, values and beliefs prior, during and after badminton instruction. Journal of Teaching in Physical Education, 15, 464-476.

Turner, A.P. (1992). A model for developing effective decision taking during game participation. Tesis Doctoral. Universidad de Oregón.

Turner, A.P. (1993, March). A model for working with students with varying knowledge structures. Paper presented at the National Convention of the American Alliance for Health, Physical Education, Recreation and Dance. Washington, DC.

Turner, A. (1996). Teaching for Understanding. Myth or reality?. Journal of Physical Education, Recreation and Dance, 67(4), 46-47, 55.

Turner, A.P. \& Martinek, T. J. (1992). A comparative analysis of two models for teaching games (Technique Approach and Game-Centered (Tactical Focus) Approach). International J ournal of Physical Education, 29(4), 15-31.

Turner, A.P. \& Martinek, T. J. (1995). An investigation into teaching games for understanding: Effects on skill, knowledge and game play. Paper from the Annual Meeting of the American Educational Research Association. San Francisco, CA: AERA.

Turner, A.P. \& Martinek, T. J. (1999). An investigation into teaching games for understanding: effects on skill, knowledge, and game play. Research Quarterly for Exercise and Sport, 70(3), 286-296.

Wright, S.; McNeill, M.; Fry, J., \& Wang J. (2005). Teaching teachers to play and teach games. Physical Education and Sport Pedagogy, 10(1), 61-82 
